\title{
The Catholic Church and the Formation of Métis Identity
}

\section{Jacinthe Duval}

This essay explores the relationship between the Roman Catholic Church and the Métis in the Red River colony in the nineteenth century. It demonstrates how missionaries, via their intellectual artifacts, have been responsible for shaping popular contemporary images of Métis culture. In analyzing the writings of missionaries, this paper also notes the ambiguity with which these individuals viewed Métis society. Priests steeped in European ecclesiastical and national values who hoped the Métis might form the basis of a new Francophone prairie society viewed some mixed-blood cultural practices as inimical to this end. From the perspective of the missionaries, the tantalizing familiarity of the French, Catholic aspect of the Métis contrasted jarringly with their 'alien' indigenous cultural and economic traits. As such, the Métis represented both a promise and a threat to the nation-building project. Although Métis identity has been stamped with the official seal of the church, the contradictions missionaries saw in this culture offer a promising avenue for the exploration of the complex processes of identity formation.

The relationship between the Roman Catholic Church and the Red River Métis has been interpreted by historians in a number of ways. Scholars such as George Bryce have portrayed the church as a nationalist institution that encouraged the Métis to "rebel" in order to satisfy French-Canadian aspirations. ${ }^{1}$ Conversely, authorities like Dom Paul Benoit and the Reverend Adrien-Gabriel Morice have depicted the clergy as the heroic, ultimate, and strongest defender of Métis rights and cultural identity. ${ }^{2}$ This paper proposes that the church instead had an essentially pragmatic relationship with the mixed-blood community.

${ }^{1}$ George Bryce, History of Manitoba (Toronto: The Canadian History Company, 1906). See also W.L. Morton, Manitoba: $A$ History, $2^{d}$ ed. (Toronto: University of Toronto Press, 1967).

${ }^{2}$ Dom Paul Benoît, Vie de Mgr Taché, 2 vols. (Montréal: Librairie Beauchemin, 1904); A.G. Morice, Histoire de l'Église catholique dans l'Ouest canadien, du Lac Supérieur au Pacifique, 1659-1915, 4 vols. (Montréal: Granger, 1921-3); Marcel Giraud, Le Métis Canadien (St. Boniface: Les Éditions du Blé, 1984, 1st ed., 1945); Robert Choquette, The Oblate Assault on Canada's Northwest (Ottawa: University of Ottawa Press, 1995), 50. 
Understanding the Métis as part of La Francophonie, the global Frenchspeaking civilization, the church defended them against Anglophone chauvinism and Canadian state aggression while simultaneously trying to excise the Native cultural traits it found so alien to its European worldview. The church did so not out of altruism, but because it saw the Métis as the raw material for a new Francophone prairie culture, bleached of all traces of the Indigenous influence. It is thus simplistic to understand the church as either friend or foe of the Métis. Rather, through the analysis of the correspondence and writings of Catholic missionaries, this essay aims to illustrate how the dynamics of Métis identity construction were shaped by men conflicted by their ambiguous views of this mixed-blood culture.

Following the events of 1869-70, the world of the Red River Métis changed irrevocably. Fearing for their lives, the three Provisional Government leaders Louis Riel, Ambroise Lépine, and William Bernard O'Donoghue fled to the United States with the arrival of Wolseley's troops at Fort Garry on 24 July 1870. With these leaders in hiding and others like Elzéar Goulet, François Guillemette, and André Nault dead, an important segment of the Métis community was deprived of its leadership. ${ }^{3}$ The Catholic Church quickly filled the void. It was left to deal with crucial issues such as the establishment of the new province of Manitoba, the amnesty question, and the increasing flow of immigrants from Ontario. As the self-appointed 'official' voice of the Métis, the church acted as the filter through which the rest of Canada perceived this culture. As such, the vision of the Métis past and present has largely been shaped by the cultural interpretation and worldview of the Red River clergy.

The prevailing ideas and movements within the French-Canadian community of the nineteenth century had considerable influence on the relationship between the church and the Métis. By 1817, the Roman Catholic Church of British North America, led by Archbishop Plessis, had been authorized by the authorities to divide and extend the boundaries of Lower Canada. It did not take long for the church to look west, especially after Plessis received a petition from inhabitants of the Red River requesting priests in 1818. This paralleled the interests of Lord Selkirk and the Hudson's Bay Company (HBC) in that both wanted to

${ }^{3}$ George F. G. Stanley, Louis Riel (Toronto: The Ryerson Press, 1963), 159-161. Elzéar Goulet was hunted by soldiers and drowned while trying to escape on 13 September, 1870. François Guillemette was shot near Pembina and André Nault was beaten and left for dead. A period of persecution of the Métis followed the arrival of militia battalions in the territory. 
establish a permanent colony at Red River. They believed that previous such attempts, as noted by Grace Lee Nute, had been subverted by the Métis inhabitants of the area. ${ }^{4}$ Following the Battle of Seven Oaks, Selkirk and the HBC decided to encourage the movement of FrenchCanadian missionaries to the colony in the hope that they would be able to pacify the Métis population. They also assumed the missionaries would facilitate the assimilation of the native population into the 'civilized' European way of life. Selkirk further hoped that the missionaries would encourage their 'flock' to abandon their nomadic existence for a settled, agricultural way of life.

When the HBC offered to grant land to the church sufficient to make it the largest owner of real estate in the colony, Plessis quickly responded favorably. In 1818, he dispatched the missionaries Joseph-Norbert Provencher, Sévère Dumoulin, and Guillaume Edge to Red River with three objectives: first, to stress that the Catholic religion demanded peace and obedience to the laws of the state and church; second, to teach the Native population to respect and obey the laws of the British Empire; and third, to create equilibrium between the North-West Company (NWC) and the HBC. ${ }^{5}$ Finally, they would proselytize the Métis by preaching the Gospel, regularizing marriages, and establishing schools. The HBC would thereafter rely on the clergy to pacify resistance to its activities. ${ }^{6}$

By 1844, twelve secular priests had made their way to Assiniboia. Of these, only six remained in Red River. However, that same year, they were reinforced by the arrival of four Grey Nuns and in 1845, the first Oblates. By 1855, the number of priests had increased to thirty, most of

4 Grace Lee Nute, Documents Relating to Northwest Missions, 1815-1827 (St. Paul: Minnesota Historical Society, 1942), xii-xiii.

${ }_{3}^{3}$ bid., 58-59.

${ }^{6}$ In 1834, for example, French and English-speaking Métis took up arms against the HBC clerk Thomas Simpson after he wounded Antoine Larocque, a Métis tripman. When things turned for the worse, Governor Alexander Christie of Assiniboia looked to Father George-Antoine Belcourt to mollify the Métis. See Gerhard Ens, Homeland to Hinterland: The Changing Worlds of the Red River Metis in the Nineteenth Century (Toronto: University of Toronto Press, 1996), 54-55. The American government also welcomed the Oblates as intermediaries between the Métis and the Sioux. Father Alexis André, for example, was employed by the American military as a peace emissary from 1863 to 1865 . See Raymond Huel, Proclaiming the Gospel to the Indians and the Métis (Edmonton: University of Alberta Press and Western Canadian Publishers, 1996), 53. 
them Oblates. ${ }^{7}$ In 1871 , the Northwest was being served by ninety-four Oblates. ${ }^{8}$ By the end of the nineteenth century, the Diocese of St. Boniface alone was served by approximately sixty secular priests and nearly 140 Oblates, along with 350 nuns. ${ }^{9}$ St. Boniface quickly became the gateway to the Catholic Northwest.

The Catholic Church of the nineteenth century was a highly structured, authoritarian, centralized, and disciplined international movement that saw as its goal the saving of humanity from the spiritual perils of the modern world. ${ }^{10}$ The Oblates themselves originated in the powerful ultramontane movement, which had tremendous influence within the church both in France and in Canada during this period. ${ }^{11} \mathrm{~A}$ reaction against Enlightenment thought and the French Revolution, ultramontanism was antithetical to the concept of the secular liberal society. Based on the exaltation of the papacy and the spread of Catholicism throughout the world, ultramontanism viewed human beings as untrustworthy and in need of protection from themselves. For humanity, there could be no salvation outside the Roman Catholic Church.

Imbued with this rigid and doctrinaire ideology, the clergy promoted the cultural and religious extension of Québec by establishing the church in Western Canada. In Montréal, Monsignor Ignace Bourget led Québec's church in a reaffirmation of its authority over the province's schools. With the assistance of Catholic newspapers, religion in Québec became a mass phenomenon that mixed language and faith as inseparable icons of French-Canadian identity. ${ }^{12}$ In the case of missions outside Québec, the church placed great value on the preservation of indigenous languages as a bulwark against Protestantization and Anglicization.

' Frits Pannekoek, A Snug Little Flock: The Social Origins of the Riel Resistance 1869-70 (Winnipeg: Watson \& Dwyer Publishing, 1991), 80.

${ }^{8}$ Donat Levasseur, Les Oblats de Marie Immaculée dans l'Ouest et le Nord du Canada, 1845-1967 (Edmonton: University of Alberta Press and Western Canadian Publishers, 1995), 106.

${ }^{9}$ Lucia Ferrete, Brève histoire de l'Église catholique au Québec (Montréal: Boréal, 1999), 69.

${ }^{10}$ Choqette, The Oblate Assault, 2-11.

"The Oblates are a missionary order present throughout the world. They were founded in France by Eugène de Mazenod in 1826 and established in Montréal in 1841 as a result of the express request of Archbishop Ignace Bourget, who wanted to attract clergy from France to compensate for the lack of priests in Québec.

${ }^{12}$ Huel, Proclaiming the Gospel, xix. 
These values informed the Oblates' approach to Native populations. They worked in a period when ideas of race and racial hierarchies were deeply rooted in the colonial European sense of superiority. One of the most popular ideas was the stage concept of civilization, wherein a given society's level of socio-cultural sophistication determined its ranking in the human family. Europeans placed themselves at the apex because they thought they had succeeded in challenging and ultimately controlling nature. Europeans, particularly missionaries, believed themselves charged with the responsibility of helping other races and classes attain a similar level of enlightenment. These men assumed that the benefits accruing from their cultural traditions and spirituality were to be shared with and taught to less fortunate groups through the process of evangelization. A fundamental tenet of this philosophy was that civilization and Christianization were inseparable concepts. One could not be Christian without also being civilized, or be civilized without being Christian. ${ }^{13}$

The Métis were the first people of the Northwest on whom the missionaries concentrated, a process, as noted, that Selkirk and the HBC had helped facilitate in their request to the church to speed the assimilation of Catholic Métis into European settler society. Working with the Métis population was therefore part of the mandate of the clergy at Red River, a task eased for the generally inexperienced missionaries in that they were dealing with a culture with which they shared some common cultural roots and considered to be already 'semi-civilized' due to its partial European origins. The assumption was that because the Métis had 'white' ancestors and were already familiar with many European cultural concepts, practicing a so-called 'folk' Catholicism, their mixed blood would make them less 'savage' than other Native groups in the area.

Missionaries often perceived the Catholic Métis as intermediaries between themselves and other indigenous groups. The first missionaries had noticed that some Native groups were familiar with Christian concepts owing to their relationship with Métis traders. The clergy thus believed that the Métis would act as the trait-d'union between the primitive and civilized worlds. In 1879, Monsignor Alexandre-Antonin Taché wrote to Deputy Minister of the Interior J. S. Dennis that "The formidable Indian question has not yet arisen in our midst...owing largely to the influence of the Half-Breed element." 14 The Oblates

${ }^{13}$ bid., 6-20.

14 Taché to Dennis, 3 February 1879, Ta4117-Ta4132, Série Taché, Fonds Corporation archiépiscopale catholique romaine de St. Boniface, Société 
repeatedly asked the government to hire Métis to work as agents and farm instructors for Native peoples, arguing that they were fully qualified and had the advantage of not needing interpreters in order to communicate. The missionaries also hoped to include a few Métis students in their industrial schools as a way of influencing Native children. However, the demands of the clergy were very rarely acted on and the church's efforts to use Métis to 'civilize' Aboriginal communities were largely unsuccessful.

Missionaries participated in the creation of what Daniel Francis calls the "imaginary Indian." 15 Their accounts and descriptions of the Indigenous populations of the Northwest contributed to the colouring of the lens through which the population of Eastern Canada would perceive the Native. The picture of the Métis that emerged was no exception to this phenomenon. The writings of missionaries, subsequently informing the work of historians, ${ }^{16}$ often described the Metis in almost identical fashion to Aboriginals. The record makes clear that most missionaries considered the Métis an inferior people and often condemned their customs as savage or pagan, perhaps in an attempt to discourage the population from adhering to them. ${ }^{77}$ In their letters to Taché, priests frequently complained that the Métis refused to exchange their seminomadic lifestyle for a sedentary agricultural one because they were too fond of pleasure. The missionaries appreciated the religious devotion of the Métis, but worried that they would not abandon certain Native traditions including what they termed médecine sanvage, the belief in the immortality of the soul and of some form of the body, as well as marriage rites and other practices inspired by Aboriginal custom.

Taché, in his Esquisse sur le Nord-Ouest de l'Amérique, dedicated a whole section to the description of Métis culture. ${ }^{18} \mathrm{He}$ described its men as beautiful, tall, strong, and well-made, 'despite' their dark complexion.

historique de St. Boniface (hereafter cited as Fonds CACRSB and SHSB respectively). Taché was referring to the violent revolts of many Native nations in the northern and western United States.

${ }^{15}$ Daniel Francis, The Imaginary Indian: The Image of the Indian in Canadian Culture (Vancouver: Arsenal Pulp Press, 1992).

${ }^{16}$ Reverend. A.G. Morice, for example, repeated the characteristics Tache had ascribed to the Métis in Esquisse du Nord-Ouest de l'Amérique. See Morice, Histoire de l'Église catholique dans L'Ouest canadien du Lac Supérieur au Pacifique, 1659-1915, 4 vols. (Montréal: Granger, 1921-1923). The artist Paul Kane used similar adjectives in 1846 to describe the Métis: Francis, The Imaginary Indian, 18.

17 Série Taché, Fonds CACRSB, SHSB.

${ }^{18}$ Taché, Esquisse. 
He admired their orientation skills, sense of observation, intelligence, hospitality, patience, and honesty, the qualities of the 'Noble Savage.' However, Taché also noted that the 'progress' of the Métis was slowed by various faults such as their love of pleasure, tendency to drink, laziness, improvidence, and lack of self-control, characteristics discouraging them from adopting the agricultural lifestyle. Charles Mestre, curé of St. Norbert in 1861, wrote that he considered the hunt a "...triste habitude qui favorise leur paresse naturelle sans les faire sortir de la pauvreté extrême qui accompagne toujours leurs fortune [sic] d'un jour." 19

Taché was much harder towards Métis women. He ascribed the 'primitiveness' of the Métis to the supposed inability of the women to properly raise their children: "Les femmes surtout, sacrifient trop souvent le bonheur véritable de ces enfants, à la jouissance de les voir, à la crainte de les reprendre ou de les élever comme il faut. ${ }^{20} \mathrm{He}$ blamed the semi-nomadic lifestyle on the failure of women to instill obedience and industriousness in their offspring, arguing that English-speaking Métis were quicker to settle on land because they had been shaped by the influence of "civilized" women much earlier. ${ }^{21}$ Like Provencher, who had spent many years looking for female teaching congregations to work at Red River, Taché hoped the Grey Nuns, who had arrived in 1844 and opened numerous missions in Métis communities, could reverse these 'negative' tendencies.

Missionaries naturally perceived the world from their own cultural perspective, the crucial determinant in their interaction with the Métis. Coming from a tradition that usually focused on the value of the land, the clergy as well as the lay leadership of the Red River colony conceived the community's future as an agricultural one, despite repeated crop failures as a result of insects, floods, and drought. ${ }^{22}$ The main focus of the work of priests, therefore, was to encourage the Métis to settle and work the land. Taché wrote that "Le plus grand tort social de nos Métis est celui d'être chasseurs." ${ }^{23}$ Taché also balanced such

${ }^{19}$ Mestre to M. M. C. Religieuse de la Visitation, 11 June 1861, 8, Série Taché, Fonds CACRSB, SHSB.

${ }^{20}$ Taché, Esquisse, 68.

${ }^{21}$ Bid., 70. Tache's comment was also an attack on writers who had argued that the Métis had not settled because their French-Canadian roots made them more primitive and less open to progress.

${ }_{22}^{2}$ Luc Dauphinais, Histoire de Saint-Boniface: À l'ombre des cathédrales (St. Boniface: Éditions du Blé, 1991), 148.

${ }^{23}$ Taché, Esquisse, 70. 
criticism with remarks indicating admiration and respect for mixedblood people. In an effort to defend the Métis after the events of 18691870, Taché argued that they were 'more civilized' than the Aboriginal population, and had a much more sophisticated culture than the roughmannered lumbermen, fishermen, and sailors working for the HBC. In his 3 February 1879 letter to Dennis, Taché added that agriculture was not the sole criteria characterizing a civilization. ${ }^{24}$

For missionaries who believed that those who refused to relinquish their inferior lifestyle in favor of the European way were ultimately doomed to extinction, and thus saw their work as essential to the survival of the Métis, the rejection by the mixed-blood people of this value system was difficult to accept. It was an especially bitter pill for those such as Provencher and Joseph-Noël Ritchot, who had come to Red River unwillingly and ached for a world resembling the one they had left behind. ${ }^{25}$ This attitude was probably another factor impelling missionaries to create a surrogate European-style society among their Métis parishioners. For priests, then, the motivation for 'improving' the Métis likely had as much to do with fostering a comfortable social environment for themselves as it did with 'saving' the mixed-blood race. It was thus a double shock for missionaries when the Métis, who had been expected to participate in the construction of their own churches and pay tithes, proved recalcitrant. Father Simonet, curé of St. Laurent, complained to Supérieur général Saint-Laurent that "Je n'ai qu'une chose à reprocher à mes gens, c'est leur paresse ou leur indifférence quand il s'agit de faire quelque chose pour l'Église."26 Some priests resorted to extortion to get what they wanted, as in the case of the curé of Pointe-à-Grouette, Jean-Baptiste Proulx, who refused to bury a dead child until the Métis built him a chapel or provided him the money to build one. ${ }^{27}$

${ }^{24}$ Taché to Dennis, 3 February 1879.

${ }^{25}$ See Dauphinais, Histoire de Saint-Boniface. He quotes many letters where Provencher asks to be allowed to return in Lower Canada. For similar letters by Ritchot, see Philippe Mailhot, "Ritchot's Resistance: Abbé Noel Joseph Ritchot and the Creation and Transformation of Manitoba" (Ph.D. diss., University of Manitoba, 1986), 8.

${ }^{26}$ Simonet to Saint-Laurent, 20 September 1869, Missions de la Congrégation des missionnaires oblats de Marie Immaculée (Paris: Typographie A. Hennuyer, 1870), 266.

${ }^{27}$ Proulx to Taché, Pointe-à-Grouette, 4 April 1872, T0432-T0435SHSB, Série Taché, Fonds CACRSB, SHSB. He wrote: “...malgré le désir qu'on a de voir cet enfant enterré ici, je ne le permettrai pas; si l'on bâtit immédiatement une chapelle, il faut que les morts aient leurs maison, ce serait les jeter comme à la 
The Catholic Church in the Northwest, as in Québec, believed that education was one of the best tools to facilitate assimilation. In 1858, the Abbé Gascon taught religion, reading, and writing in French to the young Métis of St. Laurent. Provencher tried to teach agriculture to the Métis between 1825 and 1826 and spent many years attempting to found an educational institution in St. Boniface. ${ }^{28}$ In 1829 , Angélique and Marguerite Nolin, and later the Grey Nuns, were asked to instruct Métis women in spinning and weaving, skills it was believed they would need to end their dependence on the hunt.

However, the clergy was divided on the best pedagogical means. While Provencher favoured an education rejecting all aspects of Métis culture, the Abbé Georges-Antoine Belcourt preferred blending old and new ways. Tache also approached the education of boys and girls differently. When he offered his recommendations on the establishment of industrial schools for the Métis, he argued that boys lacked not agricultural theory, but practice, noting that they often succeeded once they applied themselves at cultivation. ${ }^{29} \mathrm{He}$ therefore believed that industrial schools for Métis boys were undesirable. For girls, however, Taché took the opposite view, assuming that women raised on the Plains were ill-equipped for the tasks required in the agricultural homestead, duties he believed vital to the overall prosperity of the farm ${ }^{30}$ For Taché, industrial schools for girls were the solution to this problem. Considerable efforts were also made to develop a native clergy. In 1858, for example, Taché sent three young Métis to Québec for ecclesiastical training, an effort that did not prove fruitful. ${ }^{31}$

In the end, those who profited most from the church's educational programs were the wealthier individuals in the Métis community, generally males involved in agriculture and commerce. The cost of the Grey Nuns' boarding school in St. Boniface, for example, prevented many Métis girls from attending. Although education was also provided to poorer people, it was not up to the standards of the boarding school,

voierie en pleine prairie; que je veux une maison, assez propre du moins en dehors afin qu'elle ne nous fasse pas honte aux yeux des étrangers qui passent en si grand nombre sur ce chemin; qu'une telle batisse coute cher; que le temps des promesses est passé; que c'est du comptant qu'il faut ou rien, on ne peut commencer sans argent."

${ }^{28}$ See Dauphinais, Histoire de Saint-Boniface.

${ }^{29}$ Taché to Dennis, 3 February 1879.

${ }^{30}$ Bbid., Ta 4117 -Ta4 132.

${ }^{31}$ The three boys were Louis Riel, Louis Schmidt, and Donald McDougall. None of them entered the priesthood. 
which had the goal of attracting the richer clientele in order to raise money for other works of the Grey Nuns. ${ }^{32}$ Moreover, the educational system established by the church, modeled on the one in place in Lower Canada, was designed for a sedentary society. Children of Métis living on the buffalo hunt could only attend school for a small part of the year until they left to accompany their families on the hunt. This growing difference in educational standards would exacerbate the divisions in Métis society, which were, according to Gerhard Ens, at the root of the events of $1869 .{ }^{33}$ Nevertheless, the institutional basis for FrenchCatholic education had been established in Red River by that time.

Many missionaries chose to cope with the semi-nomadic life of the Métis by accompanying them on the hunt. According to the Métis Auguste Vermette, a missionary would join the expedition in his cart, which served both as his home and as a mobile chapel, where mass was held and the hunters blessed. ${ }^{34}$ According to George Sprenger, the priest would instruct children in catechism during the day and join the men in discussions around the campfire at night, often acting as an umpire when arguments or difficulties arose. ${ }^{35}$ While Marcel Giraud argued that this custom reinforced the nomadic lifestyle, it also allowed priests to maintain permanent contact with the Métis, increasing their ability to integrate themselves into the community. ${ }^{36}$ The priest able to adapt to the ways of his Métis parishioners was thus in a better position to wield influence in the community.

The Catholic Church also hoped the arrival of French-Canadian settlers would prove to be a civilizing influence on the Métis, encouraging them to settle. Bishop Vital Grandin, from the mission of St. Albert, wrote to Taché: “...mais j'envie ces bons canadiens qui vont si puissamment vous aider à civiliser vos Métis. ${ }^{37}$ Similarly, Father

\footnotetext{
${ }^{32}$ Dauphinais, Histoire de Saint-Boniface, 190.

${ }^{33}$ Ens, Homeland to Hinterland, 123-138.
}

${ }^{34}$ Marcien Ferland, Au temps de la Prairie: L'histoire des Métis de l'Ouest canadien racontée par Auguste Vermette, neveu de Louis Riel (St. Boniface: Éditions du Blé, 2000), 52. Auguste Vermette was born in St. Pierre-Jolys in 1891 to Toussaint Vermette and Elise Tourond. The stories he tells of the events at Red River and Batoche were passed to him by his father and his friends.

${ }^{35}$ George Herman Sprenger, "An Analysis of Selected Aspects of Métis Society, 1810-1870" (master's thesis, University of Manitoba, 1972), 38. Sprenger obtained this information from a letter written by Georges-Antoine Belcourt in 1851.

${ }^{36}$ Marcel Giraud, Le Métis Canadien, 701.

${ }^{37}$ Grandin to Taché, St. Albert Mission, 16 November 1871, T9594-9600, Série Taché, Fonds CACRSB, SHSB. 
Jean-Baptiste Proulx asked Taché to send French-Canadians to his mission at Lake Manitoba to impel the Métis to choose agriculture over hunting and fishing. ${ }^{38}$ This idea was also adopted by Louis Riel who, in 1874, wrote to Ritchot concerning the arrival of French-Canadians in the West: "Que cela aurait le plus grand avantage de faire disparaitre beaucoup de défiance entre les Métis et un certain noyau de canadiens français, de rendre l'arrivée des canadiens français, et de faire adopter aux Métis satisfaits une plus grande somme des moeurs, des traditions canadiennes françaises de telle sorte que tout en nous appelant le peuple Métis, nous soyions de fait, sans effort et de la meilleure grâce du monde, identifiés à la Province de Québec, par l'éducation."39

Riel, however, had been educated in Lower Canada, had experienced its life and culture for most of his youth, and was close friends with French-Canadian nationalists such as Joseph Royal. He also insisted on the continued existence of Métis identity and alluded to a growing problem within the Francophone community, the increasing segregation between the French-Canadian and Métis inhabitants of the new province of Manitoba. Older Métis communities experiencing an influx of FrenchCanadians were often reshaped by the demographic shift. Racial discrimination split villages such as St. Pierre-Jolys along racial and ethnic lines, with Métis concentrating on the poorer south side and most French-Canadians on the wealthier north side. ${ }^{40}$ Métis abandoned other communities and founded new settlements such as Richer and Lorette.

It is also apparent that an important segment of the church hierarchy considered the Métis inferior. Diane Payment observes that there was inequality in the distribution of work, with priests usually hiring white laywomen as sacristans or domestics and delegating menial labour such

${ }^{38}$ Proulx to Taché, Lake Manitoba, 22 February 1872, T9984-9986, Série Taché, Fonds CACRSB, SHSB.

${ }^{39}$ Louis Riel, The Collected Writings of Louis Riel Vol. I, eds. George Stanley and Raymond Huel (Edmonton: University of Alberta Press, 1985), 396-400.

${ }^{40}$ Father Guy Lavallée o.m.i., Marielle Dupont, David Dandeneau, Neil Gaudry, Lionel Allard, Augustine Abraham, Joe Bruce, Jeanne Perrault, and Marjolaine Pelletier, unknown interviewer, audio cassette, Service des archives de la Société Radio-Canada, CKSB, DAT 001-009, July 1996.This information was obtained in a series of interviews with Métis leaders conducted at the CKSB radio station. These unpublished interviews, conducted by an unknown student working on an internship, were discovered during an archival project at CKSB and subsequently acquired by the author. 
as laundering, mending, and gardening to Métis women. ${ }^{41}$ Although the Grey Nuns were relatively successful at finding adherents among the local female population, Métis nuns were not given the same opportunities as those of European origin. While some have argued that individuals like Sara Riel and Marguerite Connolly were able to rise in the ranks of the community, Diane Boyd claims this was the exception rather than the rule, observing that the most unpopular tasks tended to be given to Métis nuns. Connolly, for example, was first appointed as teacher for the boys of the colony, a job the other nuns shunned. She was then sent away to educate the Saulteaux and was regularly asked to replace absent nuns. ${ }^{42}$

Taché, however, repeatedly argued that the Métis were not inferior to the European and Canadian settlers. He wrote that "nos métis ne sont pas une race inférieure. Loin de rougir de leur origine, ils en sont fiers, et ont tout simplement, à l'égard des nations, même les plus civilisées, le sentiment de supériorité que ces dernières revendiquent, les unes sur les autres." origins, he meant their French-Canadian, not their Native roots. The Métis were only considered equal if they assimilated into FrenchCanadian society. Letters from Taché conceming the rehabilitation of the Métis in the eyes of French-Canadian society downplayed the former's 'nativeness' and emphasized their European traits, particularly their lineage as the descendents of the voyageurs. ${ }^{44}$ Ritchot, though critical of their aversion to full-time agriculture and lack of interest in the appearance of their homes, nevertheless found solace in the fact the Métis could trace their roots to the original Canadiens. ${ }^{45}$

Although the Métis were generally very religious, they were neither completely independent of nor wholly subservient to church doctrine. The clergy was able, for example, to convince the Pembina Métis to relocate to the White Horse Plains and to accept church marriage and baptism. ${ }^{46}$ Although the mariage à la façon du pays would continue

"Diane P. Payment, Un aperçu des relations entre les missionaires catholiques et les métisses pendant le premier siècle de contact (1813-1918) dans l'Ouest canadien, (Études oblates de l'Ouest 3, 1994), 151.

${ }^{42}$ Diane Boyd, "The Rise and Development of Female Catholic Education in Nineteenth Century Red River Region: The Case of Catherine Mulaire" (master's thesis, University of Manitoba, 1999), 81.

43 Taché, Esquisse, 66.

4 lbid., 66.

${ }^{45}$ Mailhot, Ritchot's Resistance, 10.

${ }^{46}$ In 1822, Provencher wrote to Archbishop Plessis: "Je tâcherai de remplir les vues de $M$. Halkett en engageant les gens à s'établir à la fourche ou dans les 
during hunting season if no priest accompanied the Métis, it was understood that it would have to be formalized in a church as soon as possible. ${ }^{47}$ The Métis never hunted on Sundays and regularly turned to their rosaries for prayer, while some were known to have built residence-chapels and provided food, buffalo robes, and transportation for certain missionaries. However, there were limits to the persuasive powers of the church. It was unable, for example, to convince the Métis to settle at Red River instead of St. François-Xavier, or prevent them from marrying outside the faith or à la façon du pays. Even though the Catholic Métis generally accepted church marriage as the culturallysanctioned means to start a family, they did not, unlike the priests, regard mixed marriages with Protestants as taboo.

Such factors helped create the environment in which the clergy faced the events of 1869. When news of the transaction between Canada and the HBC reached the Red River settlement, the majority of the local population of the colony, both French and English-speaking, was angered that it had not been consulted. According to Luc Dauphinais, the church also had misgivings about Canada's annexation of the Northwest. Since the end of the 1850s, the clergy had feared that the union and the resultant influx of immigrants, especially English Protestants from Ontario, would seriously diminish its influence in the colony. ${ }^{48}$ The boast of the Canada First Party that the Catholic Church would finally be eliminated and that the West would belong to Ontario must have only exacerbated the fears of both the clergy and the Métis.

When the Métis took up arms and gained control over Fort Garry, Tache was in Rome attending the Vatican Council, leaving the Reverend Jean-Marie Lestanc to administer the colony in his stead. When trouble broke out, Lestanc ordered the clergy to remain impartial, limiting his actions to desultory attempts to pacify the Métis, speaking against the death sentence levied against Thomas Scott and in favour of the

environs. Je pense que le départ de $\mathrm{M}$. Dumoulin et par la même la perspective d'être sans missionnaire les fera abandonner assez facilement. D'après ce projet nous serons réunis ensemble le printemps prochain à moins que les gens de Pimbina ne s'établissent assez bien pour qu'on ne puisse les desservir d'ici; ce que j’ignore encore." Provencher to Plessis, 1 September 1822, P2345-2349, Série Provencher, Fonds CACRSB, SHSB. The Métis of Pembina did leave as Provencher and the HBC desired but settled at White Horse Plains instead of the Forks.

${ }^{47}$ Ens, Homeland to Hinterland, 59.

${ }^{48}$ Dauphinais, Histoire de Saint-Boniface, 250. 
liberation of the prisoners. ${ }^{49}$ Though adamant that the clergy not involve itself in Red River politics, Lestanc nevertheless acknowledged the Provisional Govemment and used his authority to reduce the influence of the more radical members of the local Anglophone leadership, the policy adopted since Provencher's time. ${ }^{50}$ The church feared that conflict in the colony would threaten the shipment of goods to Oblate missions deep in the interior of the Northwest.

However, despite the attempts of Ritchot to remain in the background, the Métis usually remember him as one of the movement's leaders, with many accounts depicting him as counseling or leading mixed-blood people. ${ }^{32}$ Ritchot's role in these events is not completely clear, partly due to the fact that his journals have been censored, with references to his involvement with Riel either removed or effaced, probably by Ritchot himself. However, it is known that he played the role of éminence grise, receiving the Métis, offering them counsel, staging meetings in his presbytery, and providing food and provisions to their forces holding the barricade against the arrival of McDougall. Ritchot is also remembered for his contribution to the composition of the four versions of the List of Rights and the major role he played in negotiating on behalf of the Provisional Government in Ottawa. He also often acted as mediator between the divided parties of the Métis community, thus allowing Riel to deal with those who opposed him. Ritchot was able to pacify those Métis who vocally opposed both Riel and the Provisional Government, convincing them on several occasions to moderate their tone, if not gaining their outright support.

Ritchot was not the only priest to become involved in such efforts. The arrival of William McDougall as the lieutenant-governor of the Northwest Territories generally increased the sympathy of the clergy towards the Métis, especially after the anti-Catholic John Schultz and a group of fifty armed followers barricaded themselves in a home in Winnipeg. Further, many priests, including George Dugas, felt betrayed

${ }^{49}$ Dugas to Taché, St. Boniface, 29 August 1869: “À l'évêché le Rév. Père Lestang a défendu à tous les Pères et prêtres de dire un mot de politique devant qui que ce soit sous la crainte de nous compromettre." T6774-6777, Série Taché, Fonds CACRSB, SHSB.

${ }^{50}$ Mailhot, Ritchot's Resistance, 22-23.

${ }^{51} \mathrm{Huel}$, Proclaiming the Gospel, 54.

${ }^{32}$ Ferland, Au temps de la Prairie, 79-115. Vermette noted, for example, that "ll (Louis Riel) avait ben des conseils puis des ordres de Mgr Ritchot. Mgr Ritchot, il était pas mal maître chez lui, dans sa paroisse," 90. 
by the way the HBC had sold land without consulting the population. ${ }^{53}$ Fathers Louis-Raymond Giroux and Joachim Allard both openly admitted they supported the Métis, acting as chaplains for the Provisional Government and thereafter being inextricably associated with the Métis cause. Dugas, uneasy with Lestanc's order to refrain from politics, actively participated in the creation of the first List of Rights and in establishing the legitimacy of the Provisional Government. At the beginning of the troubles, he wrote to Tache that "Monsieur Ritchot les laisse dire et trouve qu'ils ont raison; moi je ne trouve pas qu'ils ont tout à fait tort. Quand ils viennent nous consulter, ce n'est pas aisé de leur répondre sans se compromettre."

What is clear is that the clergy was never directly involved in military events, generally being satisfied with a low-profile role advising Métis leaders, especially Riel, or countering opposition to the Provisional Government. It is not certain, however, that had the church wanted, it could have imposed itself as the leader of the movement, which was essentially Métis, not Catholic or French-Canadian in character. The correspondence between the priests and Taché suggests that the clergy was surprised by events, reacting to, rather than initiating them.

According to Pannekoek, when Taché returned from Rome at the express request of the Canadian government, he attempted to end the involvement of the clergy. He did this quietly in order to avoid forcing the Métis to choose between Riel and the church, since it was not at all clear that the latter would emerge victorious in such a contest. ${ }^{55}$ Giroux and Allard were forbidden to act as chaplains of the Provisional Government, in effect ending direct church involvement with the Métis political movement. Taché also apparently encouraged Riel to moderate his position. It was very important for Taché that a peaceful settlement with Canada be reached, in part because his clergy had become deeply

${ }^{33}$ Dugas to Taché, St. Boniface, 10 December 1869: "La Compagnie, l'infâme Compagnie a fait tout ce qu'elle a pu pour trahir les métis - et si McDougall n'est pas entré dans le pays ce n'est pas sa faute. Elle a fourni armes, argent, provisions à tous les ennemis de la nation, elle a fait jouer tous les ressers possibles pour écraser le peuple... Parmi les traitres à la nation, on contera [sic] désormais le Gouverneur McTavish et le Gros McKay..." T6979-6982, Série Taché, Fonds CACRSB, SHSB.

${ }^{44}$ Dugas to Taché, St. Boniface, 14 August 1869, T6734-6737, Série Taché, Fonds CACRSB, SHSB.

"s See Pannekoek, A Snug Litlle Flock, 201. For numerous references to Taché's wish to balance Métis and church interests, see House of Commons, "Report of the Select Committee on the Cases of the Difficulties in the North West Territories in 1869-70," Journals, 1874. 
implicated in the resistance. ${ }^{56}$ If Canadian or Métis forces resorted to violence, the church, being associated with the latter's cause, would no longer be seen as a neutral party and would suffer the consequences. Following the annexation of Manitoba, there was indeed a spate of attacks against the clergy. For example, despite Father Kavanagh's opposition to Riel, he was identified as a Métis sympathizer because he was a Catholic priest. He escaped an assassination attempt in 1870 in White Horse Plains. ${ }^{57}$ In 1885, at the height of the Riel trial, Taché received an anonymous letter from Winnipeg, threatening "Either a rope for Riel or a bullet for Taché." 88 This demonstrates that at least a segment of the population believed Taché and the clergy were closely linked to the Provisional Government.

Pannekoek argues that once Riel was forced to flee the settlement on the arrival of Canadian forces in the summer of 1870 , the church was allowed to fill the power vacuum and increase its influence over the Métis. He claims that following annexation with Canada in 1870 and despite the unfulfilled promise of amnesty, Métis confidence in the clergy remained sufficiently high to prevent the creation of an independent leadership. ${ }^{59}$ It is argued that when Riel and Lépine and other leaders were forced underground or imprisoned (or, in the case of Goulet, killed), Taché and several French-Canadian professionals emerged as leaders of the Métis by default. In fact, when it became obvious that the settlement would soon become a province, a few young selected Québécois came to Manitoba and assumed leadership of the French-Catholic community. ${ }^{60}$

The Canadian government shared Lord Selkirk and the HBC's assumption that the Red River Catholic Church had considerable influence over the Métis. Consequently, the government very rarely dealt directly with the Métis, attributing more influence to the church

${ }^{56}$ For references to Taché's desire for a peaceful resolution and his ambivalence over Ritchot's role in the Provisional Government and its negotiating team, see Mailhot, Ritchot's Resistance, 70,

${ }^{37}$ Stanley, Louis Riel, 161.

${ }^{38}$ Anonymous to Taché, Winnipeg, 1885, Spicilège, Fonds CACRSB, SHSB.

${ }^{39}$ Pannekoek, A Snug Little Flock, 197-212.

${ }^{60}$ These included Joseph Royal (journalist, founder of Le Métis, and member of the provincial government of Manitoba), Marc-Amable Girard (a politician who represented St. Boniface from 1870 to 1883 , briefly serving as premier in 1874), and Joseph Dubuc (journalist, politician, and lawyer. He sat for St. Norbert at the Legislature and was one of the defence counsel during the trial of Ambroise Lépine. In 1912, he became the first French-Canadian from Westem Canada to be knighted). They all seemed to work very closely with Taché. 
than it actually had. The first federal emissary to the Provisional Government was Father Jean-Baptiste Thibault, a man well-liked by the Métis community during his years as a missionary at Red River. Although he had returned to Canada in 1868, the government dispatched Thibault, along with Colonel Charles De Salaberry and HBC representative Donald Smith, back to the colony as goodwill ambassadors in 1869-70. However, as a Canadian government representative, Thibault was not trusted by the local inhabitants and his team did not obtain the results they had hoped for. The Canadian government also believed Taché would be of some use in this capacity. Recalled from Rome, he arrived in the colony in March 1870, bearing the promise of amnesty to the Provisional Government. In 1871, Father Dugas was asked by Governor Archibald to influence the position of the Métis against the Fenian threat. ${ }^{61}$ Taché later appointed himself spokesperson for the mixed-blood population in negotiations with the government, offering to federal authorities in 1879 a list of suggestions he claimed represented the interests of the Mettis throughout the Northwest. ${ }^{62}$ Such declarations reinforced the government's belief that Taché indeed was a friend of the Métis and best able to represent them, even though many were opposed to his decisions and ideas.

The tendency of the clergy has been to blame everything on Orangists, Francophobes, or Ontario anti-Catholics led by Dr. Christian Schultz and the writer Charles Mair. The resultant image of victimized Métis and French-Canadians would persist for years after the initial oppression that occurred following the arrival of the Wolseley regiment. Consequently, the church and its French-Canadian allies adopted the mission of defending Métis 'unable' to resist Orangist attacks. Taché's biographer, Dom Paul Benoît, for example, wrote “À l'origine des troubles se trouvent le parti canadien ou les Ontariens qui font peur aux Métis et donne une image négative d'une annexation avec le Canada." ${ }^{, 63}$ From this perspective, the Canada First Party and Ontario immigrants gave the Métis no choice but to opt for a violent solution to the annexation problem, rather than peaceful negotiations, as Taché would have wanted. ${ }^{64}$

${ }^{61}$ D. N. Sprague, Canada and the Métis, 1869-1885, (Waterloo: Wilfrid Laurier University Press, 1988), 78.

${ }^{62}$ Taché to Dennis, St. Boniface and 3 February 1879.

${ }^{63}$ Dom Paul Benoî, Vie de Mgr Taché, 23. In a letter to Taché, Father H. Leduc from St. Albert also blamed the Orangists for the trouble at Red River: Leduc to Taché, 1 April 1872, T10116-10118, Série Taché, Fonds CACRSB, SHSB.

${ }^{64}$ Mailhot, Ritchot's Resistance, 70. 
Following the creation of the province of Manitoba, Tache's efforts were focused mainly on the questions of amnesty and land reserves for the Métis. He spent many years working to obtain the pardon for Métis involved in the death of Thomas Scott that had been promised by George-Étienne Cartier. Having in turn assured the Métis community that the amnesty would be granted, Tache's credibility declined when its members, including its most important political figures, suffered from verbal and physical abuse at the hands of the Canadian forces and newly-arrived immigrants. ${ }^{65}$ Importantly, his efforts were calculated to attract the attention and support of nationalist Québécois. Taché appealed to their sense of patriotism, portraying the Francophone community as a martyr in order to raise funds, gamer political support, and attract new immigrants. Taché thus did not fight for the amnesty out of simple altruism, but for the larger project of creating a Francophone prairie society, as well as salvaging his reputation as a guarantor.

Control of the land was the issue that most preoccupied Taché. His letter to Dennis concerning Métis interests focused mainly on this question. ${ }^{66}$ Through Marc-Amable Girard, Joseph Dubuc, and Joseph Royal, Taché tried, unsuccessfully, to create a law that would allow the Métis to reclaim land lost to speculators. ${ }^{67}$ However, he also hoped to increase French-Canadian immigration in order to preserve FrancoCatholic influence in the new province. According to Robert Painchaud, Taché wanted to use Métis reserves, which he planned on obtaining via the Manitoba Act, as the basis for the construction of these communities. ${ }^{68}$ The Métis were expected to assimilate (or become more 'civilized' in contemporary terms) and thus strengthen the FrancoCatholic element. ${ }^{69}$ In 1874, as honorary president of the Société de colonisation de Manitoba, an organization charged with attracting Franco-Catholic settlers to the province, Tache directed the flow of Francophone immigrants arriving from Québec and the United States

65 Riel fled, Ambroise Lépine was arrested, while Elzéar Goulet was killed.

${ }^{66}$ Taché to Dennis, St. Boniface,3 February 1879.

${ }^{67}$ Robert Painchaud, Un rêve français dans le peuplement de la Prairie (St. Boniface: Éditions des Plaines, 1987), 12.

${ }^{68}$ Ibid., 3, 8.

${ }^{69}$ After searching the Taché papers for years while studying French-Canadian immigration to Western Canada, Painchaud has come to the conclusion that: "L'historique des actions entreprises par Mgr. Taché, pour faire obtenir aux Métis la part des concessions foncières leur revenant, met en évidence le fait que l'évêque était déterminé à contraindre une certaine fraction de ses ouailles à s'adapter à l'ordre nouveau, presque contre leur gré." Painchaud, Un rêve français, 14. 
towards Métis communities. His preference for group settlement demonstrates his desire to create homogeneous communities within which church, parish, school, family, and agriculture would define their boundaries.

As the Métis gradually left their communities for the interior of the Northwest, the Catholic Church became the biggest landowner in the new province. Already in 1870, the archdiocese owned the seigneurie donated by Selkirk, to which it added land east of the Seine (with the exception of fifteen acres belonging to the widow Larence) and all the lands to the north of St. Boniface. It also gradually purchased and sold land extending across Manitoba, Saskatchewan, and Alberta. ${ }^{70}$ When the church failed to prevent the Métis from leaving, many priests became very important land speculators. The goal was to acquire Métis lands and sell them to French-Canadian immigrants before they fell into the hands of Protestant speculators, thus strengthening Francophone communities. Between 1867 and 1900, for example, Ritchot purchased forty-five of St. Norbert's 256 river lots. ${ }^{\text {" }}$ Father Samoisette of St. Agathe had twenty pieces of land to sell, previously held by Métis owners. ${ }^{12}$ Others in the archdiocese including Fathers François-Xavier Kavanagh and Joseph-David Fillion, as well as the Sisters of the Precious Blood, for example, were also actively involved in land speculation. While it seems that the church strongly encouraged the Métis to remain on their lands, some members of the clergy were not always unhappy to see them leave. Father LeFloch, for example, stated that "...plusieurs vendent leurs terres et ne reviendront jamais plus, heureusement c'est tout ce qu'il y a de plus guenille sous tous les rapports, on ne perdra pas grand chose en les perdant, ces gens sont de ceux sur lesquels la civilisation n'a pas de prise..."73

In the eyes of many priests, those Métis who chose to emigrate were the ones who had refused the benefits of the 'civilization' the missionaries had brought them, and so their departure was no great loss. At the same time, however, this weakened the Franco-Catholic groupings that Taché was attempting to form. Taché did work to prevent the loss of Métis reserve lands, asking Dennis to draft a clause

${ }^{70}$ Dauphinais, Histoire de Saint-Boniface, 288.

"Mailhot, Ritchot's Resistance, 246.

72 Robert Painchaud, "French Canadian Historiography and Franco-Catholic Settlement in Westem Canada, 1870-1915," Camadian Historical Review 59:4 (1978): 458.

${ }_{73}$ Le Floch to Taché, Pembina, 2 April 1872, T10128-10131, Série Taché, Fonds CACRSB, SHSB. 
prohibiting the sale of such lands before the third generation, a time period Taché believed was necessary to allow the Métis to gradually adapt to their new lives in 'civilized' society. He noted that the creation of a Métis landowning class would strengthen the culture and prevent another outbreak of violence in Manitoba. ${ }^{7 / 4}$

Yet such efforts also earned the church a reputation as an exploiter of the Métis. Some, including Louis Riel, accused the clergy of growing rich on their misery. It is true that in the years following the creation of Manitoba, the church amassed a significant amount of land and money. Taché himself grew extremely wealthy from his land transactions, as did Ritchot. ${ }^{75}$ But Philippe Mailhot argues that this money did not remain unused. He portrays Ritchot as a community-conscious banker, selling some land to Catholics of Canadien or European background, donating other tracts to religious orders like the Trappists or the Sisters of Misericordia, and using the profits to help establish a Franco-Catholic society. ${ }^{76}$

Despite Taché's efforts to create this homogeneous community in Manitoba, dissension between Francophone Métis and FrenchCanadians remained. Although some Métis assimilated with the FrenchCanadian majority in later years, many refused to accede to the latter's leadership. Métis like Charles Nolin and Martin Jérôme, for example, encouraged their compatriots to take their fates in their own hands and openly challenged the church and French-Canadian leaders. Interviews with Métis leaders recorded in 1996 demonstrate that feelings of resentment and distrust towards French-Canadians have lingered within the Métis community, with many believing their interests had been sacrificed for those of the French-Canadian population. ${ }^{7}$ Auguste Vermette declared that "Oh! Oui, les Taché, c'était une espèce d'aristocratie canadienne-française." ${ }^{78}$ Martin Jérôme, a talented administrator who became deputy of Carillon, the first prefect of the Municipality of Salaberry, a federal Inspector of Forests and Homesteads, and a federal agent in France, claimed that in 1883, Riel told him to "Respectez vos prêtres: ils forment un grand cercle. Marchez

\footnotetext{
74 Taché to Dennis, St. Boniface, 3 February 1879.

${ }^{75}$ Mailhot, Ritchot's Resistance, 246.

${ }^{76}$ Bbid., 246-252.

${ }^{77}$ Father Guy Lavallée o.m.i., Marielle Dupont, David Dandeneau, Neil Gaudry, Lionel Allard, Augustine Abraham, Joe Bruce, Jeanne Perrault, and Marjolaine Pelletier, unknown interviewer, audio cassette, Service des archives de la Société Radio-Canada, CKSB, DAT 001-009, July 1996.

${ }^{78}$ Ferland, Au temps de la Prairie, 137.
} 
toujours autour de ce cercle, en vous inclinant; mais prenez garde d'y entrer, une fois entrés, vous aurez beau vous débattre, votre existence nationale sera bientôt éteinte." J9 Jérôme would later denounce the church's successful attempt at changing the constitution of l'Association St. Joseph de l'Union Métisse. According to Jérôme, the church managed to turn the Association into a religious institution, submitting it to ecclesiastical authority in 1910.

In 1879, the Métis had more reason to complain. In previous elections, the church had asked that their Métis and French-Canadian parishioners vote for the most educated candidate, usually a FrenchCanadian. In the 1879 provincial election, however, the situation was reversed: the French-Canadian candidate, Jean-Baptiste Desautels, was uneducated while the Métis candidate, Maxime Goulet, had received some education. All the priests of the area voted for Desautels and when the Métis complained, Taché is reported to have answered: "Après tout, apprenez que je suis Canadien-Français avant tout et qu'on est toujours plus sensible à la peau qu'à sa chemise, et vous autres Métis, si vous voulez que les prêtres soient de votre côté, faites vous des prêtres Métis." ${ }^{80}$

This is indicative of further division within the Franco-Catholic community. There was general disagreement between French-Canadians and Métis over issues like public appointments, land and financial policies, and political representation. When the Métis Charles Nolin was appointed to the Davis cabinet in 1875, he unsuccessfully tried to pressure his colleagues to appoint Métis rather than French-Canadians to government posts. By then, Nolin's anti-French message had become very attractive to some Métis, owing to Taché's unfulfilled promises of amnesty and rapid settlement of the land question, as well as deteriorating economic conditions. ${ }^{81}$ However, the church remained

\footnotetext{
${ }^{79}$ Martin Jérôme, Souvenirs d'autrefois (Winnipeg: Martin Jérôme, 1916), 13. It is not certain whether Jérôme was making this up or not. He claimed that Riel told this to many members of the Métis community, though the quote is not widespread in the extant record. It nevertheless demonstrates the attitude that some Métis had towards the church.

${ }^{80}$ Jérôme, Sorvenirs d'autrefois, 32. According to Jérôme, Taché would have said these words in a moment of exasperation during a sermon. Again, this was pronounced in public and we can assume that Jérôme would expect others to remember these words.

${ }^{81}$ Gerald Friesen, "Homeland to Hinterland: Political Transition in Manitoba 1870-1879," in Historical Papers (Ottawa: Canadian Historical Association, 1979), 33-47.
} 
important to a majority of Métis, and those who left Red River for the Northwest generally settled around missions run by Oblate fathers. ${ }^{82}$

The Métis also profited from the schools run by the church. Here, the experience of the Métis resembled that of Native students in industrial schools, although with less damaging results. J. R. Miller argues that although industrial or other schools caused great harm to Native communities, they also provided the tools students needed to become political leaders in the defence of their traditions. ${ }^{83}$ Such institutions created a literate group among Métis who would later assume leadership roles, with Louis Riel and Louis Schmidt being the most obvious examples. People like Martin Jérôme would argue that if the church had defended French-Canadian nationalism, it was perfectly normal and acceptable since most of the clergy in Red River were French-Canadian. According to him, the Métis had not been victims of the church, but of their own inaction following the events of 1869. Unlike the FrenchCanadians, the Métis had not defended their own national identity. ${ }^{84}$ Nevertheless, the church irrevocably linked two cultures uneasy or unsure of the nature of their relationship. Both were Francophone minorities in the province, and as such, had similar yet diverging interests.

In the context of these uncertainties and pressures, the Catholic Church communicated to Canadian society its perception of the Métis. Taché, through writings including Vingts années de mission dans l'Ouest canadien and Esquisse, influenced many clergy members, nationalists, and intellectuals in Québec, who in turn disseminated his ideas throughout society. The works of other clergy members in Western Canada such as Sévère Dumoulin's Notice sur les missions de la Rivière-Rouge et du Sault-Sainte-Marie and George Dugas's Histoire véridique des faits qui ont préparé le mowvement des Métis à la RivièreRouge en 1869 and Histoire de l'Ouest de 1822 à 1869: époque des troubles further contributed to this process. Québec and FrancoAmerican newspapers regularly published articles on events in the Northwest, while missionaries attempting to attract Francophone settlers to the region distributed various pamphlets. In these, the church depicted itself as the defender of Métis interests in the political arena,

${ }^{82}$ Many Métis seem to have been very devoted to the church. Augustine Abraham, in one of the CKSB interviews, speaks of the importance that religion had in her youth: CKSB, July 1996.

${ }^{83}$ J. R. Miller, Shingwauk's Vision: A History of Native Residential Schools (Toronto: University of Toronto Press, 1996), 430.

${ }^{84}$ Jérôme, Soivenirs d'autrefois, 31-32. 
transmitting its views of the Red River population across the country. Taché's description of the Métis in Esquisse has been repeated by contemporaries and historians such as Louis Riel and Arthur S. Morton. ${ }^{85}$ The status of missionaries as eyewitnesses and participants in the events at Red River helped make their vision of Métis society the authoritative one insofar as Canadian society at large was concerned.

The role of the church in the affairs of the Métis is therefore crucial to understanding socio-political conditions at Red River during the nineteenth century, a period Irene Spry refers to as the transition from homeland to hinterland culture, or to a proto-capitalist and industrial community ${ }^{86}$ The great majority of the clergy seem to have understood the Métis as a group that needed to be 'perfected,' believing that through the church's work, the Métis would move beyond their semi-primitive state to become full members of the civilized world by virtue of their father's blood. As such, the church can be seen as interested in the welfare of the Métis, but most often in terms of the potential this group offered in forming the basis of a new, syncretic French-Canadian prairie society, rather than for its merits as a unique culture in its own right. Indeed, the indigenous aspects of Métis culture were seen as a threat to this goal that had to be excised.

While the church has often declared itself the defender of the Métis, and was often the only organization to speak on their behalf, its actions reflected the predominant colonial perspective informing its worldview. As the self-proclaimed arbiter of Métis interests, the church was in turm perceived by the Canadian public as the authoritative voice of this group. The government, the newspapers, and immigrants discovered the Métis through a clergy that used language and ideas already familiar to their Canadian audience. It remains to be seen if the Métis, who have historically been defined by a church with primarily Franco-Catholic loyalties in mind, will be able to develop an identity based on their own unique social, cultural, and economic priorities, re-fashioning, in the process, the cultural lens through which Canadian society has perceived them for more than a century.

${ }^{85}$ Riel, "Mémoire sur les Métis: Les trois principaux défauts des Métis du Montana," in The Collected Writings of Louis Riel, 81-84; Arthur S. Morton, A History of the Canadian West to 1870-71 (Toronto: Thomas Nelson \& Sons, 1939), 651; Giraud, Le Métis canadien.

${ }^{86}$ Irene Spry, "The Great Transformation: The Disappearance of the Commons in Western Canada," in Man and Nature on the Prairies, ed. R. A. Allen (Regina: Canadian Plains Research Centre, 1976), 36. See also Friesen, Homeland to Hinterland, 47. 